Vol.45, n. 3 : pp. 333-342, September 2002 ISSN 1516-8913 Printed in Brazil

\title{
Thermic Variation in Incubation and Development of Pantanal Caiman (Caiman crocodilus yacare) (Daudin, 1802) Kept in Metabolic Box
}

\author{
Maristela Parra Miranda ${ }^{1}$; Gentil Vanini de Moraes $^{1 *}$; Elias Nunes Martins ${ }^{1}$; Luis Carlos \\ Pinto Maia $^{2}$ and Orlando Rus Barbosa ${ }^{1}$ \\ ${ }^{I}$ Departamento de Zootecnia, Universidade Estadual de Maringá, Av. Colombo, 5790, 87020-900, Maringá - \\ Paraná, Brazil, ${ }^{2}$ Criadouro de Animais Silvestres Jacará, Distrito de Guaragi, Ponta Grossa, Paraná, Brazil
}

\begin{abstract}
Thirty-two eggs of Pantanal caiman (Caiman crocodilus yacare) (Daudin, 1802) were incubated at $30^{\circ} \mathrm{C}$. After 20 days of incubation at $30^{\circ} \mathrm{C}$, the remaining eggs were distributed in the following way: seven at $34^{\circ} \mathrm{C}$, seven at $32^{\circ} \mathrm{C}$, six at $30^{\circ} \mathrm{C}$ and six at $28{ }^{\circ} \mathrm{C}$. At $32{ }^{\circ} \mathrm{C}$ and $34^{\circ} \mathrm{C}$ a $100 \%$ hatchability was obtained while at $30{ }^{\circ} \mathrm{C} 83.3 \%$ and at $28{ }^{\circ} \mathrm{C}$ $66.6 \%$. After hatching, the animals were kept for 120 days at the same temperature of their final incubation. Weight (g) control and morphometric $(\mathrm{cm})$ analysis were carried out. The statistic design was totally randomized and the data were treated by regression analysis showing a quadratic behavior $(p<0.05)$. It was found that weight, total length (TTL), tail length (TL), snout- vent length (SVL), head length (HL), eye length (EL), snout length (SL), midpoint snout width $(\mathrm{MSW})$, head width $(\mathrm{HW})$, width of snout at nostrils $(\mathrm{NW})$, distance between limbs $(\mathrm{DBL})$ showed a higher development at the temperature range from $31.2^{\circ} \mathrm{C}$ to $31.8^{\circ} \mathrm{C}$ and circumference of belly at $30.0^{\circ} \mathrm{C}$.
\end{abstract}

Key words: Caiman, development, incubation, temperature, thermic variation

\section{INTRODUCTION}

The Caiman crocodilus yacare (Daudin, 1802) can be found in Bolivia, Paraguay, Uruguay, Argentina and Southwestern of Brazil, more specifically from Mato Grosso Sul (Paraguay river) to the state of Paraná - Paraná river (King and Burke, 1989). It is considered a medium size alligator, reaching 2.5 to 3.0 meters at adult age. In Brazil, nesting takes place in the rainy season, with an average of 21 to 38 eggs being laid (Groombridge, 1987). In the reproductive handling, the artificial incubation is a stage to increase caiman culture. This method is widely used other crocodilian cultures (Joanen and McNease, 1975; Joanen and McNease, 1987; Joanen et al., 1987; Breyer, 1987; Verdade et al., 1992; Larriera, 1993). Generally, artificial incubation is processed with constant temperatures from the beginning to the hatching of the eggs. This aspect deserves discussion once that under natural nest conditions constant temperature does not occur during the whole incubation period.

In each nest occurs a temperature variation in relation to the position of the eggs and to room or environment temperature and this variation determines differences in development and sex (Joanen, 1969; Ferguson and Joanen, 1983). During the natural incubation, these occurs a

\footnotetext{
${ }^{*}$ Author for correspondence
} 
gradual temperature increase from the beginning to the hatching (Webb and Smith, 1984). According to these authors, the gradual temperature may facilitate development of eggyolk integralization and hatching.

Investigations on thermic variation during incubation have been carried out in order to verify the effects of temperature on the characteristics of the young alligators which were confirmed to increase in the last third of the embryo development, the phase of its fastest growth (Congdon et al., 1995). The embryo formation was divided into three general stages: the first two comprise the initial formation until the sexual definition period, and the last stage corresponds to its growth (Ferguson, 1985). Ferguson, 1987, evaluated the stages of embryonic development of crocodilians by working with eggs of three different species (Alligator mississipiensis, Crocodilus johnstoni, Crocodilus porosus) at different temperatures. In Alligator mississipiensis, the incubation increase in temperature, (taking into account the viability limits for these species), accelerated the development of organogenesis initial phases. On the other hand, at $34^{\circ} \mathrm{C}$ the gonadal development was decelerated in relation to the development at $30^{\circ} \mathrm{C}$, but the embryonic development was faster at $34^{\circ} \mathrm{C}$ when compared with that of $30^{\circ} \mathrm{C}$ and $28^{\circ} \mathrm{C}$.

Data of the thermic influence on the initial growth have also been obtained. Joanen et al., 1987 observed significant effects of incubation temperature (from $29.4^{\circ} \mathrm{C}$ to $32.8^{\circ} \mathrm{C}$ ) on final embryonic development and weight gain in animals kept at $30^{\circ} \mathrm{C}$, which showed to be even more intense at higher incubation temperatures. Pinheiro et al (1992) analyzed the effects of 22.8 , 26, 29.5 and $32^{\circ} \mathrm{C}$ temperatures on the development of Pantanal caiman and found a low food uptake and growth at $28.8^{\circ} \mathrm{C}$ but high food uptake and growth between 29.5 and $32^{\circ} \mathrm{C}$ up to 71 days of life. On the other hand, Vianna et al., 1995, studying the effect of 30,32 and $34^{\circ} \mathrm{C}$ temperatures on the growth of young of Caiman latirostris, observed a higher total growth between 32 and $34^{\circ} \mathrm{C}$ but they did not observed difference between 32 and $34^{\circ} \mathrm{C}$ temperatures.

The bibliographical survey revealed very few works on thermic variation in incubation and no work on the particular species Caiman crocodilus yacare. Therefore, the present experiment to evaluate the effect of thermic variation during the incubation period and the effects of different temperatures on after hatching development was understaken.

\section{MATERIALS AND METHODS}

The experiment, was carried out for 175 days during April $1^{\text {st }}$ through September 22 $2^{\text {rd }}, 1998$.

The stage from incubation to hatching was carried out at Criadouro de Animais Silvestres Jacará in the district of Guaragi, municipality of Ponta Grossa, state of Paraná, Brazil, and the growing stage was carried out at the Laboratory of Animal Reproduction of Universidade Estadual de Maringá.

On April $4^{\text {th }}$, 1998, thirty-two eggs were collected from the same nest, with an average weight of $61.28 \mathrm{~g}$ each, showing opaque bands. Two of the eggs were opened to verify the embryonic stage of the nest and later used to analyze the embryonic development. The remaining thirty eggs were weighted, measured, marked with pencil and placed in an incubator, according to the model proposed by Verdade et al., 1992 , at $30^{\circ} \mathrm{C}$. An $82-$ L $643 \times 403 \times 290 \mathrm{~mm}$ polystyrene foam box was used as incubator containing a $7 \mathrm{~cm}$ watersheet, two perforated silverware supporters on which was placed a plastic tray containing moistened vermiculite as support and cover for 25 -Watt lights were fastened and controlled by $0.2^{\circ} \mathrm{C}$ - precision thermostat, made and checked in the laboratory of physics, at Universidade Estadual de Maringá. An orifice to place the thermometer was made at the middle height of one of the walls.

During the incubation, other four eggs were opened, to evaluate the embryonic development, two on April $8^{\text {th }}$ and the two on April $18^{\text {th }}$. The six embryos (the two opened earlier and two just mentioned) were examined, weighted and described according to the model proposed by Ferguson, 1987.

After 20-day incubation at $30^{\circ} \mathrm{C}$, the remaining eggs were redistributed at four different temperatures: seven each at 34, and 32 and six each at 30 and $28^{\circ} \mathrm{C}$. Each egg was placed individually in a plastic ice-cream box containing vermiculite, which was a modified incubation model different from that created by Verdade, 1992, thus facilitating the identification control of each egg at the hatching moment. 
After hatching, the newborn animals were kept in a growing box containing water warmed to their original hatching temperature: seven animals in a box at $34^{\circ} \mathrm{C}$, seven at $32^{\circ} \mathrm{C}$, five at $30^{\circ} \mathrm{C}$ and three at $28^{\circ} \mathrm{C}$. Each animal was identified with colored beads fastened by smooth thin wire at the final third of the tail, fortnightly weighted and morphometrically analyzed. The measurements taken were the following: total length (TTL)-from the extreme snout front to the extreme tail tip; tail length (TL)-from the front end of vent to the extreme tail tip; snout-vent length (SVL)-from the extreme snout front to the front end of vent; head length (HL) from the extreme snout front to the back surface of occipital condyle; eye length (EL)-total eye socket length; snout length (S)from the front end of the snout to the front eye socket edge; width of snout at mid -point (MSW); head width (HW)-distance between the lateral surfaces of jawbone condyles; width of snout at nostrils (NW)-distance between the lateral surfaces of jawbone front end; distance between members (DBM); circumference of belly (CB)belly circumference at the middle region of the animal. For weighting, a $0.01 \mathrm{~g}$-precision Sartorius 1202 MP balance was used and for morphometric analyses, an Italian $0.05 \mathrm{~mm}$-precision M-Metrica caliper, a millimetric ruler, a transparent $1 \mathrm{~mm}$ precision ruler and a $1 \mathrm{~mm}$-precision tape measure. Each growing box was kept tilted, providing $2 / 3$ of the bottom area moistened and $1 / 3$ dry. 150 -Watt aquarium electric heaters coupled to a $0.2^{\circ} \mathrm{C}-$ precision thermostat were used to keep and control temperature. Water temperature was checked every day through an Incoterm $0.1^{\circ} \mathrm{C}$-precision thermometer for the possibly necessary adjustment of the thermostat, which was always made within the precision limits, once the experiment was carried out in a nonairconditioned room which suffered the influence of room temperatures higher than the temperatures tested in the experiment.The open part of the boxes was covered with a plastic screen fastened with elastic cord to prevent the animals from escaping.

The diet was constituted of ground cattle meat including $0.01 \%$ vitaminic premix Jacaré-Phós. The animals were fed at libitum five days a week taking into account the minimal food requirement proportionate to $25 \%$ live weight, the animal's appetite and losses during feeding. It must be emphasized that the vitaminic premix contained zinc bacitracine, an antifungic active principle.

For feeding a polystyrene recipient was placed on the dry area of the box. The animals were fed at 5 p.m. and the next morning they were taken out of the boxes which were cleaned and new clean water was added at the appropriate temperature to avoid thermic shocks.

The experimental design was totally randomized, in which the different temperatures constituted the treatments and the hatched animals were the repetitions. The collected data were submitted to regression analysis taking into account the treatment and animal ages, using Secretary of State for Agriculture's software, after Euclides (1993), in the following statistical model:

$Y_{i j k}=b_{o}+b_{1} T_{i}+b_{2} T_{i}^{2}+b_{3} I+b_{4} I^{2}+e_{i j k}$, in which:

$\mathrm{Y}_{\mathrm{ijk}}=$ observation made to animal $\mathrm{j}$ at temperature $\mathrm{i}$ at age $\mathrm{k}$

$\mathrm{b}_{0}=$ constant

$b_{1}=$ linear regression coefficient of the observation $\mathrm{Y}$ in function of temperature $\mathrm{i}$

$\mathrm{b}_{2}=$ quadratic regression coefficient of observation $\mathrm{Y}$ in function of temperature $\mathrm{i}$

$b_{3}=$ linear regression coefficient of observation $Y$ in function of age $j$

$b_{4}=$ quadratic regression coefficient of observation $\mathrm{Y}$ in function of age $\mathrm{j}$

$\mathrm{T}_{\mathrm{i}}=$ water temperature $\mathrm{i}=1 ; 2 ; 3 ; 4$

$\mathrm{I}_{\mathrm{j}}=$ animal age $\mathrm{j} ; \mathrm{j}=1 ; 120$ days

$\mathrm{e}_{\mathrm{ijk}}=$ aleatory error associated to each observation $\mathrm{y}_{\mathrm{ijk}}$

\section{RESULTS}

General data on artificial incubation are presented in Table 1. In Table 2, a brief description of the six embryos collected in the period of the first 18 days of incubation at $30^{\circ} \mathrm{C}$ is presented. The embryos collected increased five times their weight from the first to the $18^{\text {th }}$ day of artificial incubation. In Table 3, the most important correlations of the parameters measured such as weight $\mathrm{x}$ TTL, weight $\mathrm{x}$ TTL, weight $\times$ TL, weight $\times$ SVL, weight $x$ CB, TTL $x$ TL, TTL $x$ HL, SVL $x$ HL and SVL $x$ SL are shown. The correlations showed to be significant $(\mathrm{p}<0.01)$. 
Table 1 - Data of the effect of thermic variation on Pantanal caiman(Caiman crocodilus yacare) eggs

\begin{tabular}{ccccccc}
\hline IT $\left({ }^{\circ} \mathrm{C}\right)$ & $\mathrm{FT}\left({ }^{\circ} \mathrm{C}\right)$ & $\mathrm{N}$ & $\mathrm{AT}($ days $)$ & $\mathrm{H}(\%)$ & $\mathrm{MT}(\%)$ & NSA \\
\hline 30 & 28 & 6 & 69.2 & 66.63 & 50 & 3 \\
30 & 30 & 6 & 61.4 & 83.3 & 16.6 & 5 \\
30 & 32 & 7 & 57.2 & 100 & 0 & 7 \\
30 & 34 & 7 & 56.7 & 100 & 0 & 7 \\
\hline
\end{tabular}

IT = Initial incubation temperature $\left({ }^{\circ} \mathrm{C}\right) ; \mathrm{FT}=$ Final incubation temperature $\left({ }^{\circ} \mathrm{C}\right) ; \mathrm{N}=$ Number of eggs; AT $=$ Average incubation time (days); $\mathrm{H}=$ Hatchability (\%); MT= Pre and posthatching mortality(\%); NSA= Number of post-hatching surviving animals

Table 2 - Morphological description of six embryos of Pantanal caiman (Caiman crocodiles yacare) collected during the initial 18 days of incubation at $30^{\circ} \mathrm{C}$

\begin{tabular}{|c|c|c|c|c|}
\hline Egg opening day & $\operatorname{Egg~} n^{\circ}$ & Embryo weight (g) & $\begin{array}{c}\text { Morphological stage } \\
\text { (Ferguson,1987) }\end{array}$ & $\begin{array}{c}\text { Description of morphological } \\
\text { stage * }\end{array}$ \\
\hline $\begin{array}{c}\text { April } \\
1^{\text {st }} \\
1998\end{array}$ & 6 & 1.19 & 17 & $\begin{array}{l}\text { Paddle form hands and feet } \\
\text { presenting }\end{array}$ \\
\hline $\begin{array}{c}\text { April } \\
8^{\text {th }} \\
1998\end{array}$ & 24 & $\begin{array}{l}0.03 \\
2.80\end{array}$ & 20 & $\begin{array}{l}\text { Small portion of interdigital } \\
\text { membranes still remaining } \\
\text { between toes and between digits; } \\
\text { whitened body. }\end{array}$ \\
\hline & 29 & 2,77 & 19 & $\begin{array}{l}\text { Presence of interdigital } \\
\text { membranes that characterize the } \\
\text { paws as paddles in which digits } \\
\text { are already internally defined. }\end{array}$ \\
\hline $\begin{array}{c}\text { April } \\
18^{\text {th }} \\
1998\end{array}$ & 01 & 5,03 & 22 & $\begin{array}{l}\text { Dorsal skin pigmentation; } \\
\text { absence of interdigital } \\
\text { membrane; definite round claws; } \\
\text { there are four protuberances on } \\
\text { the head between the eye } \\
\text { sockets. }\end{array}$ \\
\hline
\end{tabular}

* descriptions made during the experiment by the author

Table 3 - Correlations of the parameters weight, total length, tail length, snout-vent length, circumference of belly, head length, snout length of Caiman crocodilus yacare sample specimens

\begin{tabular}{cc}
\hline Variables & Correlations \\
\hline Weight x TTL & 0.86 \\
Weight x TL & 0.82 \\
Weight x SVL & 0.84 \\
Weight x CB & 0.87 \\
TTL x TL & 0.96 \\
TTL x SVL & 0.95 \\
TTL x HL & 0.89 \\
SVL x HL & 0.87 \\
SVL x SL & 0.92 \\
\hline
\end{tabular}


The eggs whose incubation temperature was reduced from $30^{\circ} \mathrm{C}$ to $28^{\circ} \mathrm{C}$ suffered the severest damages. Two of the six eggs were found dead after 51 days of incubation: the embryos were already formed but dead. The hatching of the four remaining eggs resulted in premature animals that still had a small portion of the vitelinic sac exposed outside the abdominal cavity. One of the eggs hatched on the $68^{\text {th }}$ day of incubation, but the animal showed a spent aspect and died the following day. The other three animals hatched, on the $68^{\text {th }}, 69^{\text {th }}$ and $71^{\text {st }}$ day of incubation, respectively. From the eggs kept at $30^{\circ} \mathrm{C}$, four hatched with 61 to 62 days of incubation, while the remaining egg was opened on June $2^{\text {rd }}$ and showed the presence of a living embryo, though extremely retarded in relation to viteline sac absortion, needing approximately other 20 to 25 days to hatch. The eggs incubated at $32^{\circ} \mathrm{C}$ and $34^{\circ} \mathrm{C}$ presented a $100 \%$ hatchability rate and the incubation time for each egg was, 54, 55, 56, 57, 58,60 and 60 days in one case and 55, 56, 57, 57, 58 and 58 in the other case, respectively. Data on the initial development were collected for 120 days.

The parameters measured after the statistical analysis resulted in regression equations correlating treatment and age of the animals which are in the growing curve obtained through regression analysis presented in Figure I to Figure $X I$. The regression equations were quadratic and statistically significant $(p<0.05)$, except for the parameter width of nostrils, in which no effect occurred.

Through equation derivation the following temperatures were obtained: weight $=31.2^{\circ} \mathrm{C}$; $\mathrm{TTL}=31.6^{\circ} \mathrm{C} ; \quad \mathrm{TL}=31.7^{\circ} \mathrm{C} ; \quad \mathrm{SVL}=28^{\circ} \mathrm{C} ;$ $\mathrm{HL}=31.8^{\circ} \mathrm{C} ; \quad \mathrm{EL}=31.6^{\circ} \mathrm{C} ; \quad \mathrm{SL}=31.3^{\circ} \mathrm{C}$; $\mathrm{HW}=31.8^{\circ} \mathrm{C} ; \quad \mathrm{DBL}=31.8^{\circ} \mathrm{C} ; \quad \mathrm{SW}=31.3^{\circ} \mathrm{C}$; $\mathrm{CB}=30.6^{\circ} \mathrm{C}$. The variable $\mathrm{NW}$ did not vary $(p>0.05)$ in the treatments at no age.

\section{DISCUSSION}

The problems met in the final incubation stage at $28^{\circ} \mathrm{C}$ probably occurred because of the temperature reduction from 30 to $28^{\circ} \mathrm{C}$. The egg incubation at constant temperature of $28^{\circ} \mathrm{C}$ (Breyer, 1987) resulted in $94 \%$ hatchability rate, which indicated that $28^{\circ} \mathrm{C}$ not the problem per se but the reduction during incubation from $30^{\circ} \mathrm{C}$ to $28^{\circ} \mathrm{C}$. On the other hand, Webb and CooperPreston,1989, verified that nests with temperatures between $28.1^{\circ} \mathrm{C}$ and $29^{\circ} \mathrm{C}$, and between $33.1^{\circ} \mathrm{C}$ and $35^{\circ} \mathrm{C}$ showed a high mortality rate. According to these authors, from 11 eggs incubated in laboratory at $28^{\circ} \mathrm{C}$ eight embryos hatched prematurely but were normal, one embryo died before hatching and two during the hatching process. As for the egg that did not hatch at the sam e time with the others nested at $30^{\circ} \mathrm{C}$ and had its development retarded, it may be concluded that the eggs in the same nest are differently affected by the thermic treatment depending on each developing potential. As for the temperature increase from 30 to 32 and $34^{\circ} \mathrm{C}$ a $100 \%$ hatchability rate was obtained, but two embryos (one from the $32^{\circ} \mathrm{C}$ nest and one from the $34^{\circ} \mathrm{C}$ nest) hatched prematurely presenting incomplete absorption of the viteline sac and incomplete closure of abdominal cavity. It could be possible that external noises and the voicing of the other animals within the eggs may have affected the premature hatching of embryos as described by Joanen, 1969. Incubations at constant temperatures from 28 to $34^{\circ} \mathrm{C}$ were carried out with alligator eggs. At $31^{\circ} \mathrm{C}$, the hatchability was $18 \%$ higher that at $29.4^{\circ} \mathrm{C}$ and $60 \%$ higher than at $33.9^{\circ} \mathrm{C}$ (Joanen and McNease, 1979), which showed the highest hatchability within the temperature limits from $31{ }^{\circ} \mathrm{C}$ to $31.7^{\circ} \mathrm{C}$. Other temperatures as 32.8 with $83 \%$ hatchability rate, 31.7 with $82.1 \%, 30.6$ with $76.2 \%$ and 29.4 with $68 \%$ were also tested (Joanen and Mcnease, 1991). The results of 100\% hatchability found at 32 and $34^{\circ} \mathrm{C}$ in the present experiment were in disagreement with those of the author cited, but this success come be due to thermic variation once that a higher temperature used in the final growing phase of the embryo facilitated the hatching of animals with minimum of characteristic variation. It might have result in a more homogeneous hatching (Congdon et al., 1995).

In the twenty-second morphological stage of the embryos here collected and compared to those of Ferguson, 1987, is experiment, they showed to be completely formed and growing in size and weight. The embryonic developments of Alligator mississipiensis, Crocodilus johnstoni and Crocodilus porosus were compared through morphometric analysis by Deeming and Ferguson, 1990. 


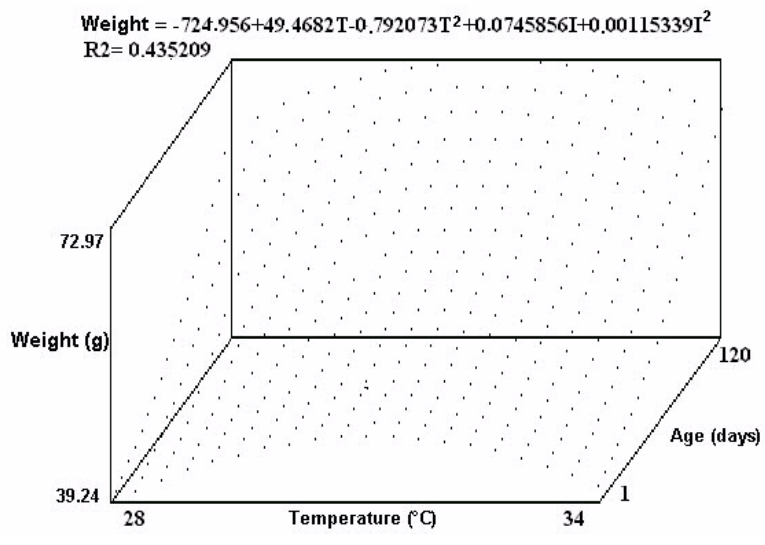

Figure 1 - Weight (g) of caiman due to temperature $\left({ }^{\circ} \mathrm{C}\right)$ up to 120 -day age. $\mathrm{T}=$ Temperature, $\mathrm{A}=$ Age, R2 $=$ Regression coefficient.

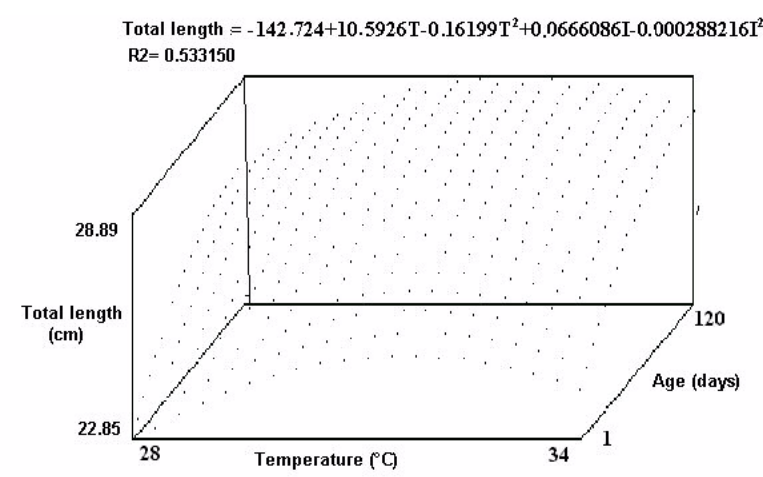

Figure 2 - Total length $(\mathrm{cm})$ of caiman due to temperature $\left({ }^{\circ} \mathrm{C}\right)$ up to 120 -day age. $\mathrm{T}=$ Temperature, $\mathrm{A}=$ Age, $\mathrm{R} 2=$ Regression coefficient.

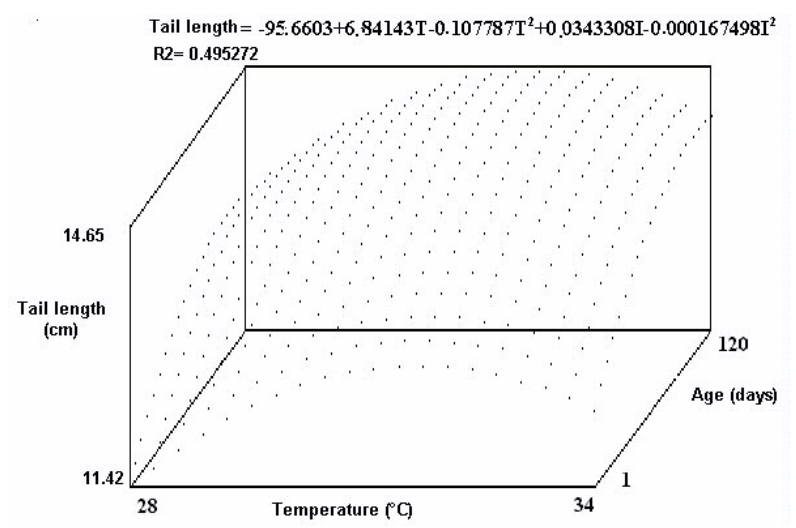

Figure 3 - Tail length (cm) of caiman due to temperature $\left({ }^{\circ} \mathrm{C}\right)$ up to 120 -day age. $\mathrm{T}=$ Temperature, $\mathrm{A}=$ Age, $\mathrm{R} 2=$ Regression coefficient.

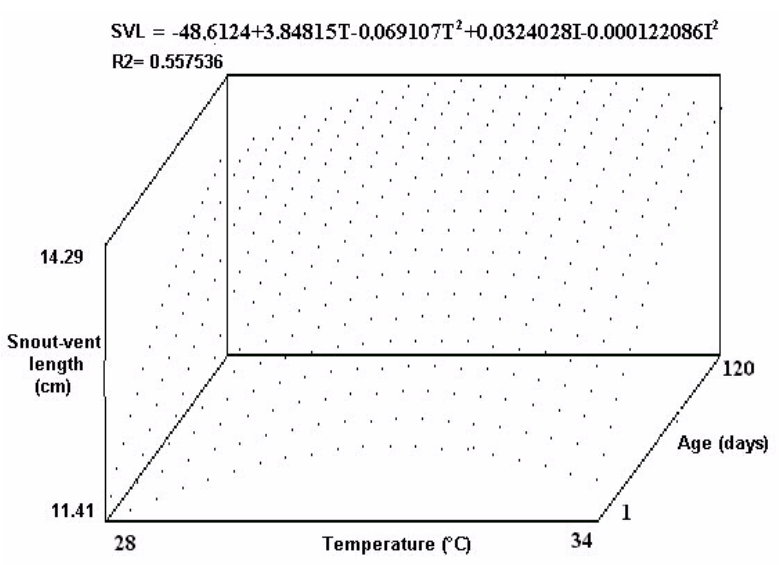

Figure 4 - Snout-vent length $(\mathrm{cm})$ of caiman due to temperature $\left({ }^{\circ} \mathrm{C}\right)$ up to 120 -day age. $\mathrm{T}=$ Temperature, $\mathrm{A}=$ Age, R2 = Regression coefficient.

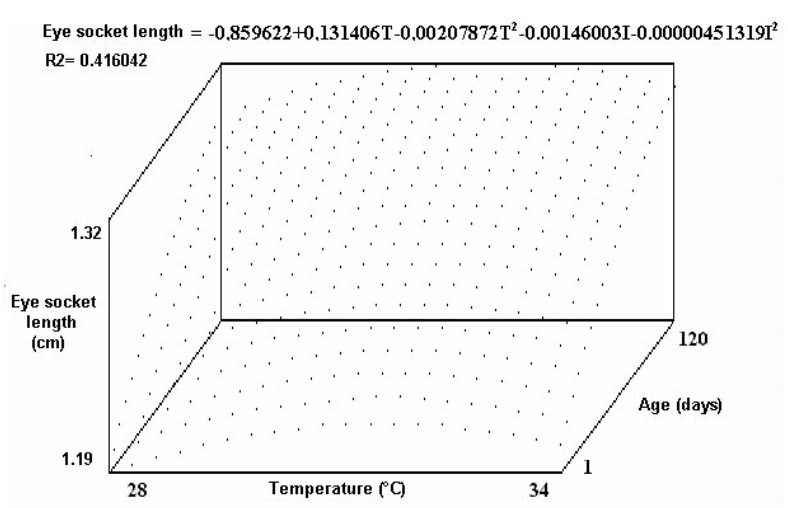

Figure 5 - Eye length $(\mathrm{cm})$ of caiman due to temperature $\left({ }^{\circ} \mathrm{C}\right)$ up to 120 -day age. $\mathrm{T}=$ Temperature, $\mathrm{A}=$ Age, $\mathrm{R} 2=$ Regression coefficient.

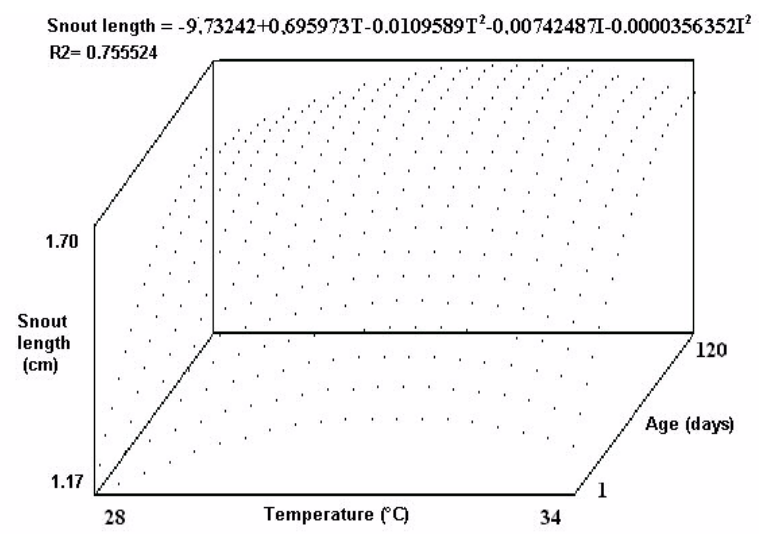

Figure 6 - Snout length $(\mathrm{cm})$ of caiman due to temperature $\left({ }^{\circ} \mathrm{C}\right)$ up to 120 -day age. $\mathrm{T}=$ Temperature, $\mathrm{A}=$ Age, $\mathrm{R} 2=$ Regression coefficient. 


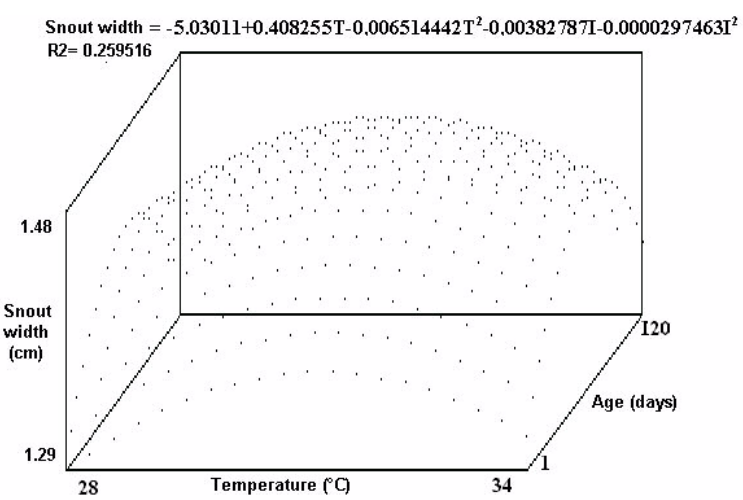

Figure 7 - Snout width $(\mathrm{cm})$ of caiman due to temperature $\left({ }^{\circ} \mathrm{C}\right)$ up to 120 -day age. $\mathrm{T}=$ Temperature, $\mathrm{A}=$ Age, $\mathrm{R} 2=$ Regression coefficient.

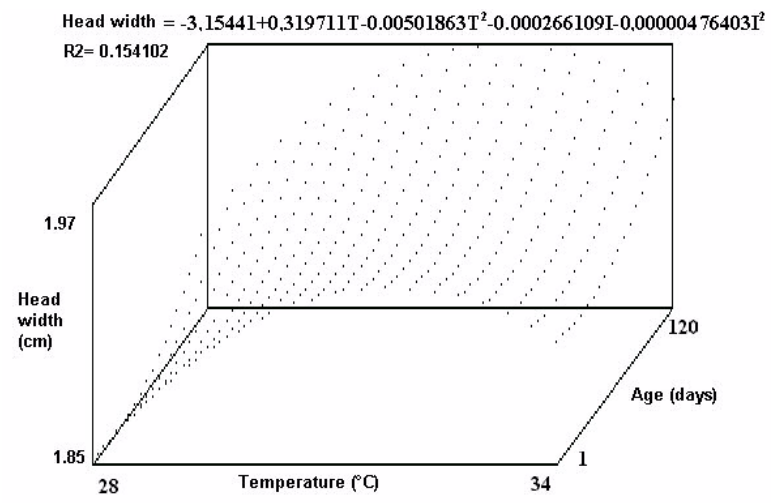

Figure 8 - Head width $(\mathrm{cm})$ of caiman due to temperature $\left({ }^{\circ} \mathrm{C}\right)$ up to 120 -day age. $\mathrm{T}=$ Temperature, $\mathrm{A}=$ Age, $\mathrm{R} 2=$ Regression coefficient.

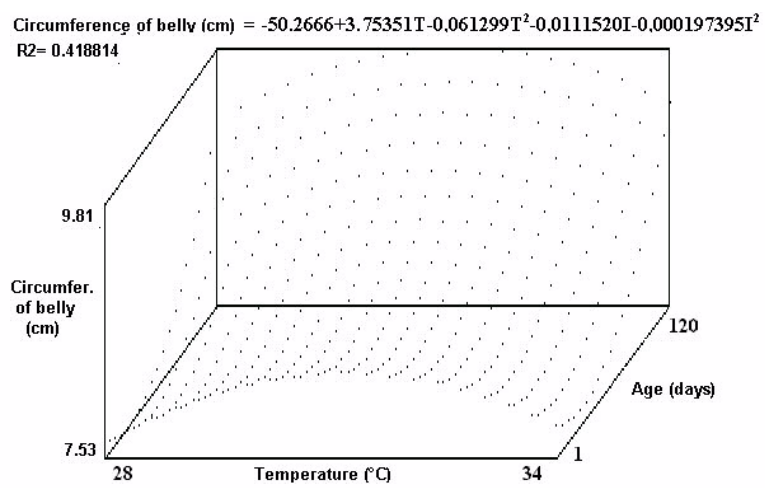

Figure 9 - Circumference of belly $(\mathrm{cm})$ of caiman due to temperature $\left({ }^{\circ} \mathrm{C}\right)$ up to 120-day age. $\mathrm{T}=$ Temperature, $\mathrm{A}=$ Age, R2 = Regression coefficient.

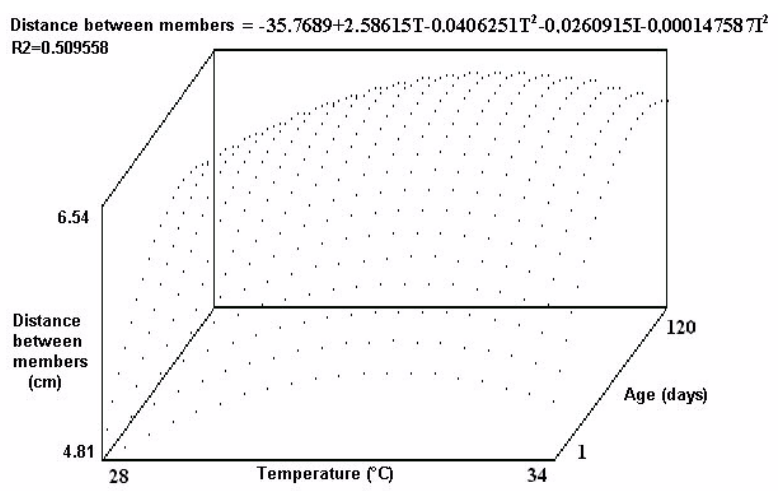

Figure 10 - Distance between members $(\mathrm{cm})$ of caiman due to temperature $\left({ }^{\circ} \mathrm{C}\right)$ up to 120 -day age. $\mathrm{T}=$ Temperature, $\mathrm{A}=$ Age, $\mathrm{R} 2$ = Regression coefficient.

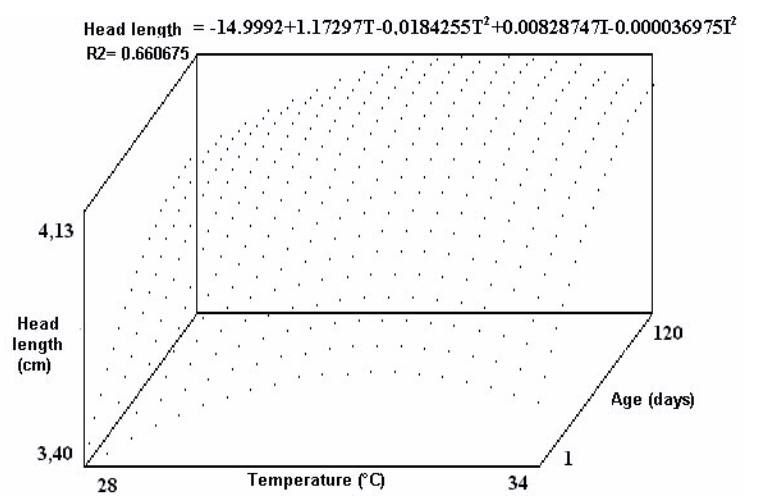

Figure 11 - Head length (cm) of caiman due to temperature $\left({ }^{\circ} \mathrm{C}\right)$ up to 120 -day age. $\mathrm{T}=$ Temperature, $\mathrm{A}=$ Age, $\mathrm{R} 2=$ Regression coefficient.

These authors reported that the fast increase in embryonic mass initiated in morphological stage 20, with species-specific differences in morphological stages 23, 24 and 25. The differences in relation to total length initiated in stage 10 reaching their maximum increase in morphological stages 24 and 25. Taking into account that at collecting the embryos had already reached stage 17, it may be possible that the sex of the animal was already defined, though no embryonic tissue analysis was then made. As for post-hatching development, the animals kept at $34^{\circ} \mathrm{C}$ showed the strongest appetite while the animals kept at $28^{\circ} \mathrm{C}$ showed the minimum appetite, but both had their development retarded when compared to the other treatments which evidences that extreme thermic treatments are detrimental to the animal's growth. The best 
temperature treatment for weight gain was $31.22^{\circ} \mathrm{C}$, close to the best temperature $29.5^{\circ} \mathrm{C}$, followed by the second best, $32^{\circ} \mathrm{C}$, found by Pinheiro et al., 1992. The weight gain verified in this experiment, however, is lower than $91.21 \mathrm{~g}$ found by Pinheiro et al., 1992, probably due to the high population density. The best temperature, $31.6^{\circ} \mathrm{C}$, for total length $(28.89 \mathrm{~cm})$ was similar to that found in experiments with alligators $\left(30.6{ }^{\circ} \mathrm{C}\right.$ and $31.7^{\circ} \mathrm{C}$ ) by Webb and Cooper-Preston, 1989, and 32 oC by Vianna et al., 1995, for Caiman latirostris. The tail length depends on the size of the egg (Deeming and Ferguson, 1990). A high correlation (0.96) between total growth and tail length was observed, which may explain the best temperature, $31.7^{\circ} \mathrm{C}$, found in the present experiment, close to $31.6^{\circ} \mathrm{C}$, observed by those authors for total length. The greatest tail length was $14.65 \mathrm{~cm}$ which indicates an increase of 3.23 $\mathrm{cm}$ from the beginning to the end of the experiment. Snout-vent length represents approximately half of the total length of the animal and this explains the same $31.6^{\circ} \mathrm{C}$ for snout-vent length and total length found in this experiment. The increase of $2.88 \mathrm{~cm}$ in SVL, in this experiment, however, showed to be lower than 3.8 cm observed by Santos et al., 1993, when the animals were fed with fish and kept at $32^{\circ} \mathrm{C}$ water temperature. The animals presented the greatest head length $(4.13 \mathrm{~cm})$ and greater head width $(1.97 \mathrm{~cm})$ at $31.8^{\circ} \mathrm{C}$ (Figures 8 and 11$)$. The best performance in snout length $(1.70 \mathrm{~cm})$ and snout width $\left(1.48 \mathrm{~cm}\right.$ ) was observed at $31.3^{\circ} \mathrm{C}$ (Figures 6 and 7). The values found for head length are similar to those found by Santos et al., 1993, who observed heads with 4.1 to $4.4 \mathrm{~cm}$ length at $32^{\circ} \mathrm{C}$ temperature. As for head development, particularly regarding snout, it is a species-specific feature (Deeming and Ferguson, 1990) but differences from animal to animal may not be excluded, in the same nest, because different sizes of heads are features normally attributed to sexual dimorphism (Verdade et al., 1997). The longest distance between members $(6.54 \mathrm{~cm})$ was observed at $31.8^{\circ} \mathrm{C}$, which is similar to the best SVL growth temperature at $32^{\circ} \mathrm{C}$ (Pinheiro et al., 1992) and the best total length temperature also $32^{\circ} \mathrm{C}$ (Vianna et al., 1995). The development of the eyes only influences the size of the embryos after morphological stage 24, which corresponds to the period of 45 to 50 days of life (Ferguson, 1987; Webb and Manolis, 1987; Deeming and Ferguson,
1990). Alligator eggs were incubated at $29^{\circ} \mathrm{C}$, $31^{\circ} \mathrm{C}, \quad 32^{\circ} \mathrm{C}$ and $33^{\circ} \mathrm{C}$, but none of these temperatures affected the size of the eyes (Alsteadt and Lang, 1995), which is discordant from the optimal temperature, $31.6^{\circ} \mathrm{C}$, found in this experiment and close to $32^{\circ} \mathrm{C}$ found by Pinheiro et al., 1992, for the total growth. According to Verdade, 1987, eye length may be related to sexual dimorphism features and, as in the present experiment only one nest was used as a sample, there may have been a predominance of one sex. The parameters of eye length and circumference of belly, however, have not been registered yet in literature for this species. The option to measure the circumference of belly was made because of the possibility to industrialize the animals hide from the trunk region for whose development the best temperature found was $30.6^{\circ} \mathrm{C}$. This temperature is different from the values found by Pinheiro et al., 1992 and by Vianna et al., 1995, for other species. The significant quadratic effect (0.87) of the circumference of belly and weight (Table 3), at $31.2^{\circ} \mathrm{C}$, close to that observed for circumference of belly $\left(30.6{ }^{\circ} \mathrm{C}\right)$, may also serve as an indicative for weight gain. Although an optimal temperature for the best development of each parameter was found, it may be noticed that in comparison to the data observed in literature the growth values found here are lower. The differences between growth rates may be attributed to stocking density, nutritional variation and sexual differences. The stocking density used in this experiment for $30^{\circ} \mathrm{C}, 32^{\circ} \mathrm{C}$ and $34^{\circ} \mathrm{C}$ was approximately the double of that usually recommended ( 1 animal per 9 to $12 \mathrm{~cm}^{2}$ ). Only one type of diet was used with the addition of mineral salt. It is highly probable that the mineral salt dose used was not sufficient to meet the total requirement of the animals. Different authors have also suggested that a diet variation may induce a higher growth rate in the animal. No parasitological analysis was made, therefore, health problems of the animals may not be discarded, though no occurrence of problematic animals was observed during the experiment, except for the death of one animal in the last week of the experiment, which was lean and refused to eat.

Initial artificial incubation temperature changes from 30 to 32 and $34^{\circ} \mathrm{C}$, after the $18^{\text {th }}$ day for Caiman crocodilus yacare resulted in a higher hatchability rate that at $28^{\circ} \mathrm{C}$. The best post- 
hatching growth rate was obtained at $31^{\circ} \mathrm{C}$ and $32^{\circ} \mathrm{C}$ temperatures.

\section{RESUMO}

Trinta e dois ovos de Caiman crocodilus yacare foram incubados, inicialmente, à temperatura de $30^{\circ} \mathrm{C}$. Durante a incubação foram retirados seis ovos para se conhecer o estágio embriológico e peso, além de breve descrição dos embriões. Após 20 dias de incubação a $30^{\circ} \mathrm{C}$, os ovos foram assim distribuídos: sete em $34^{\circ} \mathrm{C}$, sete em $32^{\circ} \mathrm{C}$, seis em $30^{\circ} \mathrm{C}$ e seis em $28^{\circ} \mathrm{C}$. Em 32 e $34^{\circ} \mathrm{C}$ obteve-se $100 \%$ de eclodibilidade, em $30^{\circ} \mathrm{C}-83,3 \%$, e a 28 ${ }^{\circ} \mathrm{C}$ - 66,6 \%. Após a eclosão os animais permaneceram durante 120 dias na mesma temperatura de incubação final. Foi realizado controle de peso $(\mathrm{g})$ e análise morfométrica $(\mathrm{cm})$. $\mathrm{O}$ delineamento estatístico foi inteiramente casualizado, e os dados foram analisados por regressão, que mostraram um comportamento quadrático $(p<0,05)$. Constatou-se que o peso, comprimento total, comprimento da cauda, comprimento focinho-cloaca, comprimento da cabeça, comprimento do olho, comprimento do focinho, largura do focinho, largura da cabeça, largura das narinas, distância entre membros tiveram maior desenvolvimento na faixa de 31,2 a $31,8^{\circ} \mathrm{C}$ e, a circunferência da barriga a $30,6^{\circ} \mathrm{C}$. A redução de 30 para $28^{\circ} \mathrm{C}$, na incubação artificial, desencadeou eclosão de animais prematuros. Portanto, a redução da temperatura de 30 para $28^{\circ} \mathrm{C}$, durante a incubação artificial não é recomendada, e maior crescimento pode ser obtido entre 31 a $32^{\circ} \mathrm{C}$.

\section{REFERENCES}

Alsteadt, J. and Lang, J. W. (1995), Incubation temperature affects body size and energy reserves of hatchling American Alligators (Alligator mississipiensis). Physiol. Zool., 68, 76-97.

Breyer, F. R. S. (1987), Técnicas Para a Coleta, Transporte e Incubação Artificial de Ovos de Caiman crocodylus yacare (Daudin, 1802), (Crocodylia: Alligatoridae). Corumbá, MS: Embrapa - CPAP, (EMBRAPA - CPAP. Comunicado Técnico, 8). 8 pp.

Congdon, J. D.; Fischer, R. U. and Gatten Jr., R. E. (1995), Effects of incubation temperatures on characteristics of hatchiling American Alligators. Herpetol., 51, 497-504.
Deeming, D. C. and Ferguson, M. W. J. (1990), Morphometric analysis of embryonic development in Alligator mississipiensis, Crocodylus johstoni and Crocodylus porosus .J. Zool., Lond., 221, 419-439.

Euclides, R. F. (1993), Manual de utilização do programa SAEG (Sistema de Análise Estatística e Genética). Viçosa, Mg: UFV, Central de Processamento de Dados. 59 pp.

Ferguson, M. W. J. and Joanen, T. (1983), Temperature dependent sex determination in Alligator mississipiensis. J. Zool., 200, 143-177.

Ferguson, M. W. J. (1985), The reproductive biology and embryology of crocodilians. In- Biology of Reptilia.14. Development A. Gans, C., Biillet, F. and Maderson, P. F. A .(Eds). New York: John Wiley and Sons.

Ferguson, M. W. J. (1987), Post-laying stage of embryonic development for crocodilians. InWebb, G. W. J.; Manolis, S. C. and Whitehead, P. J. Wildlife management: crocodiles and alligators. Surrey Beatty and Sons Pty., Chipping Norton, Australia. pp. 427-444.

Groombridge, B. (1987), The distribuition and status of world crocodilians. In- Webb, G. W. J.; Manolis, S. C. and Whitehead, P. J. Wildlife management: crocodiles and alligators. Surrey Beatty and Sons Pty., Chipping Norton, Australia. pp. 9.

Joanen, T. (1969), Nesting Ecology of Alligators. InProceed. 23 ${ }^{\text {rd }}$ Annual Conf. South. Assoc. Game Fish Comm. pp. 141-151.

Joanen, T. and McNease, L. (1975), Notes on the reproductive biology and captive propagation of the American Alligator. In- Proceed. 29 $9^{\text {th }}$ Annual Conf. South. Assoc. Game Fish Comm. pp. 407-415.

Joanen, T.and McNease, L. (1979), Culture of the American alligator. Inter. Zoo. Yearbook, 19, 61-66.

Joanen, T.and McNease, L. (1987), Alligator Farming Research in Lousiana, USA. In- Webb, G. W. J.; Manolis, S. C. and Whitehead, P. J. Wildlife management: crocodiles and alligators. Surrey Beatty and Sons Pty. Chipping Norton, Australia. pp. 329-340.

Joanen, T.; McNease, L. and Ferguson, W. J. (1987), The effects of egg incubation temperature on posthatching growth of American Alligator. In- Webb, G. W. J.; Manolis, S. C. and Whitehead, P. J. Wildlife management: crocodiles and alligators. Surrey Beatty and Sons Pty. Chipping Norton, Australia. pp. 533-537.

Joanen, T.and McNease, L. (1991), Managing the alligator egg and hatchling. Proceed. Inten.Trop.Anim.Product. pp.193-205.

King, W. F. and Burke, R. L. (1989), Crocodilian, Tuatara, and Turtle species of the world. In- $A$ taxonomic and geographic reference ed. Association of Systematics Collections, Washington. pp. 5-6. 
Larriera, A. (1993), La conservation y el manejo de Caiman latirostris en Santa Fé, Argentina. InWorkshop sobre conservação e manejo do jacaré-depapo-amarelo. 3, ESALQ/USP, Piracicaba. Anais... ESALQ/USP, Piracicaba. pp. 61-69.

Pinheiro, M. S; Santos, S. A and Silva, R. A. (1992), Efeito da temperatura da água sobre o crescimento inicial de Caiman crocodilus yacare (Crocodilia, Crocodilidae). Rev. Brasil. Biol., 52, 161-168.

Santos, S. A ., Pinheiro, M. S. and Silva, R. A. (1993), Efeitos de diferentes dietas naturais no desenvolvimento inicial de Caiman crocodilus yacare (Crocodilia Alligatoridae). Rev. Soc. Bras. Zoot., 22, 406-412.

Verdade, L. M., Lavorenti, A and Packer, I. U. (1992), Manejo reprodutivo do jacaré-de-papo-amarelo (Caiman latirostris) em cativeiro. In- Verdade, L. M. and Lavorenti, A. (eds.). Workshop sobre Conservação e Manejo do jacaré-de-papo-amarelo (Caiman latirostris). 3, ESALQ/USP, Piracicaba, Anais... ESALQ/USP, Piracicaba, Brasil. pp. 143-152

Vianna, V. O.; Lavorenti, A and Sarkis, F. (1995), Efeito da temperatura no desenvolvimento de filhotes de jacaré-de-papo-amarelo, Caiman latirostris (Daudin, 1802) em cativeiro. In- Reunião da Sociedade Brasileira de Zootecnia, 32, Brasília, DF. Anais.... Brasília : SBZ. pp. 391-393.
Webb, G. J. W. and Cooper-Preston, H. (1989), Effects of incubation temperature on crocodiles and the evolution of reptilian oviparity. Amer.Zool., 29, 953-971.

Webb, G. J. W. and Smith, A. M. A. (1984), Sex ratio and survivorship in the Australian freshwater crocodile Crocodylus johnstoni In- M. W. Ferguson. The Structure, Development and Evolution of Reptiles. Academic Press: London. pp. 319-355.

Webb, G. J. W. and Manolis, S. C. (1987). Methods for retrieving crocodilian embryos. In- Webb, G. W. J.; Manolis, S. C. and Whitehead, P. J. Wildlife management: crocodiles and alligators. Surrey Beatty and Sons Pty., Chipping Norton, Australia. pp. 423-426.
Received: August 11, 1999; Revised: February 13, 2001; Accepted: June 22, 2001. 